\title{
Women's Politics as Radical Politics: Reconceptualising Women's Historical and Contemporary Political Practices with the Work of Luce Irigaray
}

\author{
Belinda Eslick
}

University of Queensland

\begin{abstract}
In her paper 'Feminist History as National History: Writing the Political History of Women', Australian feminist historian Marilyn Lake urged scholars to create new narratives about women's political histories. Lake's subsequent work has informed approaches to feminist histories that challenge liberal feminist values and adherence to the narrative of the 'waves' of feminism by drawing scholars' attention to women's political histories outside of political institutions and parties. Lake argued that 'masculinist historiographical and conceptual frameworks' had rendered women's political histories invisible, and she called on scholars to develop new conceptual frameworks for understanding women's diverse, and mostly non-institutional, political theories and practices. Such new frameworks, Lake argued, could allow us to challenge the idea that women's political history had been one of 'failure'. As a non-historian engaging with Lake's work, I also see the value in developing such frameworks for understanding women's continuing non-institutional political activity in contemporary Australia. In this paper, I bring Lake's discussions of nineteenth- and twentieth-century Australian feminist political theories and practices together with French feminist philosopher Luce Irigaray's writing on politics. I explore how considering Irigaray's work could allow us to acknowledge women's political activities in ways that not only render them visible but also identify their potential radicalness.
\end{abstract}


It is common for women and women's influence to be missing from recorded political histories and national mythologies, including in Australia. And where there is a positive account of a 'great' or influential woman in political histories (in dominant as well as some feminist histories) it is commonly to document or tell the story of a female 'first'. For example, in Australia, we celebrate the first women to have run for election to government or become Members of Parliament, the first women who were allowed to vote, the first female state premier or prime minister, and so on. Women barely featured at all in Australia's political history before activists, feminist historians and other feminist scholars intervened-particularly from the 1970s. But, in dominant histories and contemporary public discourse, there has been and remains a tendency to fixate on those exceptional women who were or are able to break into (or lean into-as some recent liberal feminist attitudes encourage women to do) typically male realms, roles or occupations. This aspect of a woman's story is also likely to receive a dominating focus, even if a woman lived an active and influential political life before or after her entrance into institutional, 'formal', male-dominated politics. This is still arguably so in contemporary Australian public discourse and national mythologies: women are lauded for breaking through barriers but typically little else, and the women who have breached the 'frontiers' of men's worlds are celebrated.

It is less common to hear stories about women who have been influential from the places where women do already commonly dwell or have conventionally dwelt. These include, most notably, 'informal' or noninstitutional sites as well as the realms of society that are closest to the home. The scarcity or invisibility of women in recorded political histories and dominant cultural political narratives is—as some feminist historians have shown-no indication of women's idleness and not only because women have been lowly regarded in Australian society and by non-feminist historians. Rather, it is largely because of the promotion of particular ideals that have typically privileged men's stories and experiences and either explicitly or implicitly silenced (through excluding or devaluing) women's stories and experiences. The privileging of certain ideals or places in society means that women only become visible, or worth mentioning, when we reach a particular (male) standard. This means that much of women's activity—despite its significant influence—goes unacknowledged and unvalued. 
Some feminist historians in Australia, like the authors of Creating a Nation, showed that, in this sense, women were missing from dominant histories by default. ${ }^{1}$ This was because Australian histories typically privileged masculine ideals, endeavours and realms of society (that is, primarily government and the state, the military and war, and the frontiers of colonial development) and women have been mostly absent from or silenced in those realms. Women were not absent from dominant political histories because we had been politically idle but because women had been politically active outside of the most culturally privileged, male-dominated realms of society. One of the authors of Creating a Nation, Marilyn Lake, argued further with her 1996 article 'Feminist History as National History: Writing the Political History of Women' that privileging masculine realms of society and ignoring (and thereby devaluing) the sites where women act, perpetuated what she called the 'women-as-political-failures thesis'. ${ }^{2}$ Lake argued, in other words, that women's history was typically framed only according to women's apparent failure to achieve the political positions that men had. Lake argued that women were characterised as political failures despite women's energetic, engaged and influential political activity in different realms of society, and through different modes of 'doing' politics. The political practices that many women developed throughout the late nineteenth and twentieth centuries-and which continue into the twenty-first century-were, as Lake has helped to demonstrate, largely non-institutional and non-party.

With her subsequent work, particularly in Getting Equal: The History of Australian Feminism (1999), Lake documented some examples of women's non-institutional political activity in Australia. She argued, further, that these examples suggested that feminism in Australia had indeed 'flourished in the interwar years, decades that, in many ways, could be characterised as the golden age of the woman citizen. ${ }^{3}$ Such an interpretation, as Lake noted, was counter to the popular characterisation of this period by other feminist scholars as a disappointment because it had been marked by a relative lack of women in positions of institutional political power. Lake argued that to understand women's political histories more fully (and not as a history characterised by failure), scholars needed to look

1 Patricia Grimshaw, Marilyn Lake, Anne McGrath and Marian Quartly, Creating a Nation (Melbourne: McPhee Gribble/Penguin Books Australia, 1994).

2 Marilyn Lake, 'Feminist History as National History: Writing the Political History of Women', Australian Historical Studies, 27, no. 106, (1996): 154-69, doi.org/10.1080/10314619608596005.

3 Marilyn Lake, Getting Equal: The History of Australian Feminism (Sydney: Allen \& Unwin, 1999), 9. 
beyond masculine realms of society. She also argued that scholars needed to develop and apply new conceptual frameworks that would allow us to think differently about politics and about women's varied experiences as citizens in Australia.

As an academic in feminist theory and gender studies (that is, a nonhistorian) considering women's political practices in contemporary Australia, I have found Lake's work to be immensely beneficial for challenging perceptions about women's political engagement. Public discourse and political science surveys continue to measure women's political engagement according to a particular, masculine standardand the 'women-as-political-failures thesis' that Lake described persists, I argue, in contemporary Australia. ${ }^{4}$ With this paper, I consider Lake's call to 'develop new conceptual, analytical frameworks that will allow us to see more clearly the complexity of women's political history'. I respond by exploring how such feminist frameworks might be developed by engaging with French feminist philosopher Luce Irigaray-particularly her early feminist writing on politics and her philosophical contributions to rethinking women's subjectivities. Doing so can, as I argue, contribute new feminist resources for understanding women's political histories as well as contemporary experiences of politics.

Irigaray began publishing feminist work in the 1970s with her first feminist text Speculum of the Other Woman (published in French in 1974 and translated into English in 1985). Her work (along with other feminist scholars and writers in France at this time, like Hélène Cixous and Julia Kristeva) has made an enormous impact on feminist thought in the West. This has, notably, been through contributing to what have been considered as 'difference' feminisms, through her thinking on sexual difference, her rethinking of the categories of 'subject' and 'other' in response to the work of Simone de Beauvoir, and her critiques of egalitarian feminist perspectives. I will suggest with this paper that considering Irigaray's work in the context of women's non-institutional political practices-together with Lake's historical work-could allow us to acknowledge women's political activities in ways that not only render them visible but also identify their potential radicalness. I suggest that it is possible to show how women's distinct modes of doing politics can be reconceptualised

4 Lake, 'Feminist History as National History', 158.

5 Ibid., 161. 
as disruptions to the normativity of the masculine political subject and to phallocentric notions of citizenship, and not merely as ways of 'making do' with a lack of masculine political power.

I discuss Irigaray's feminist and philosophical (and feminist philosophical) perspectives and, specifically, her early work on women's relationships to politics. This includes her argument, put forth initially in This Sex Which is Not One (1977/1985), that women should develop new modes of doing politics that would not emulate existing, masculine political practices. I then consider how these perspectives can be thought with Lake's feminist historical work to develop critical feminist approaches to understanding women's political activities. Further, I also consider Irigaray's more recent work on politics, where she advocates for a politics, generally, based in relationality, care and with a greater attention to life and 'natural' rhythms. Finally, I begin to explore how this work might enable ways of reconceptualising the aspects of women's non-institutional political activity that have been conventionally considered to be the greatest barriers to women's 'legitimate' citizenship. This includes, for example, women's proximity to the home, local community and so-called 'private' realms of society. I question whether consideration of an Irigarayan ethic of politics could, in some ways, allow us to conceptualise these aspects of women's politics as signs of a radical rather than deficient politics.

\section{Looking to Where Women Actually Were: The Impacts of 'Difference' Feminisms}

Lake argued that the omission of women's non-institutional sites of political action from recognition in cultural and historical narratives had contributed to the presumption that women's political history had been one of 'woeful disappointment'. 6 This was coupled with criticism from feminist activists and scholars in the 1970s and 1980s who, Lake said, had suggested women in Australia had 'wasted the vote' by failing to enter parliamentary positions in high numbers in the twentieth century. Lake argued that we therefore needed a new approach to telling women's political histories - one that would acknowledge the distinct modes of politics that women employed outside of institutions-in order to counter the limited narrative of women's political 'failure'.

6 Lake, 'Feminist History as National History', 159.

7 Ibid. 
Lake's book Getting Equal: The History of Australian Feminism (1999) was itself a contribution to the new narrative that she advocated. It documented the vast and rich political contributions and influence from mostly white women in colonised Australia in the nineteenth and twentieth centuries. Many of the women documented in Lake's work practised what she has since described as a kind of 'white maternalist' politics outside of institutional politics-in clubs and societies, homes and public halls, and in sites of grassroots activism. ${ }^{8}$ Lake argued, for example, that 'contrary to the popular idea that the women's movement languished with the achievement of the vote', feminism in Australia had indeed 'flourished in the interwar years, decades that, in many ways, could be characterised as the golden age of the woman citizen'. ' Lake characterised this period as an immensely productive time of women's political advocacy and organising in Australia, where many women (particularly socially privileged women) lobbied for a broad range of social and political change. Further, many women had developed, as Lake found, 'their own mode of doing politics, eschewing for the most part the traditional male-dominated political parties in favour of mobilising women at the grassroots level'. ${ }^{10}$ Importantly, Lake was suggesting that women had been developing distinct ways of practising politics and were actively critiquing the status quo of parties and parliaments, describing women as 'leading theorists and practitioners of citizenship'. ${ }^{11}$

This influence, however, had not been documented or celebrated in recorded histories, as Lake argued in Getting Equal, writing:

That women were leading theorists and practitioners of citizenship, that they were outspoken advocates for proportional representation, a welfare state, Aboriginal citizenship, the custody rights of Aboriginal and non-Aboriginal mothers and the importance of international law seemed to be of no consequence to the men who document, and still document, our political history. It was as if political women had never existed. ${ }^{12}$

8 Marilyn Lake, 'Subjective Femininities and Feminist Subject Positions: White Maternalism and the Will to Power', Paper presented at 'Feminisms and Feminities', Lilith: A Feminist History Journal Symposium, Melbourne, November 2019.

9 Lake, Getting Equal, 9.

10 Ibid., 13.

11 Ibid., 6.

12 Ibid. 
Lake compelled us to counter the popular characterisation of women's political history as one of failure by telling feminist history as national history. This would involve going beyond a strategy of inserting women into an existing set of ideals or narratives_about nation-building, society or politics-and would instead involve radically reviewing the kinds of stories that we record, retell and canonise through radically rethinking what we deem politically, culturally and historically significant. Such an approach expands beyond a strategy of searching for traces of women in men's places, as Lake suggested previous scholars had largely done. Instead, it would aim to acknowledge, tell and retell new kinds of narratives that recognise women's distinct perspectives and experienceswhether as workers, mothers, teachers, farmers, writers, community leaders, grandmothers, business owners, artists, and so on. Doing so could acknowledge women's experiences as inherently valuable and significant, rather than only valuable according to their proximity to male-dominated institutions. In other words, the radical aspect of Lake's call was that women's histories should be acknowledged and valued according to what women were already doing or where we already were-an important feminist conceptual shift.

Lake also showed the limitations of conventional political science approaches to documenting women's political histories. She critiqued what she described as the 'reduction of the history of politics to parties and parliaments' and urged scholars to move beyond 'a Whiggish tale of women's entry into parliament and the counting of female politicians. ${ }^{13}$ To tell women's histories accurately and meaningfully, it was necessary to look beyond parties and parliaments. She suggested, for example, that empirical studies on women's participation with institutional politics were limited, writing:

Whereas political science models of investigation have provided valuable empirical studies of women's integration into parliaments and parties ... we also need to develop new conceptual, analytical frameworks that will allow us to see more clearly the complexity of women's political history and the vital interrelationship of public and private life. ${ }^{14}$

13 Lake, 'Feminist History as National History', 160.

14 Ibid., 161. 
Such new conceptual frameworks would, Lake argued, enable us to recognise 'citizen politicians', including Rose Scott, Jean Daley, Edith Jones, Bessie Rischbieth, Cecilia Downing, Mary Montgomery Bennett and Jessie Street, 'as key figures in Australian political history'. ${ }^{15}$ It would also allow us, Lake said, 'to see women's political history as a history of creativity and accomplishment'. ${ }^{16}$

Accounts of women who have been historically influential from typically feminine realms of society are rare for many reasons. The places where women have typically acted from are, first, not culturally valued in the ways that masculine sites (including institutional, state, industrial, commercial or military ones) are. But the sites of women's non-institutional political activity (including non-institutional, non-commercial, non-industrial places like the home and other 'private' spaces, women-only places or organisations, the local community, and grassroots sites of activism) are also often characterised by women's oppression. Many feminist scholars and activists are therefore wary of valorising these sites of women's political activity as this might risk appearing to justify women's social and political subordination or falling into essentialist claims about women's social roles. Any attempts to valorise women's experiences outside of male-dominated, privileged realms of society must therefore be approached critically, with clear acknowledgement of both the privilege and oppression that shape women's experiences of politics. For example, women who practised politics in the ways that Lake's work described were engaging in real struggle, as - and on behalf of-oppressed and subordinated subjects. But these women were also relatively privileged and were able to practise the kinds of politics they did because they had access to time and resources that many other women, including Indigenous Australian women, nonEuropean women, elderly women and many poor and working-class women, typically did not. Lake's work is clear to emphasise that many socially privileged women used their relative power to advocate on behalf of more vulnerable women-and vulnerable subjects generally.

Failing to critically consider the sites where women have practised politics (even when these are oppressive sites), however, risks reaffirming the privileged position of the male political subject and the normativity of men's political ideals and institutions. With recognition of these tensions, scholars like the authors of Creating a Nation have argued that it is not 
enough to simply insert women into the dominant, and predominantly masculine, narrative about Australia. Lake, for example, suggested other Australian feminist scholars, including Anne Summers in Damned Whores and God's Police (1975) and Miriam Dixson in The Real Matilda (1976) had done this. ${ }^{17}$ Even if Summers and Dixson had done so to highlight women's subordination in patriarchal society, they were arguably limited in their critical capacity because they had remained within a patriarchal framework. According to Lake, they therefore served implicitly to reinforce that framework and narrative, which assumed the normative citizen was a masculine subject. Lake argued that it was necessary, instead, to cultivate a new story that acknowledged and respected women's experiences and perspectives as central to Australia's story. As Lake wrote, she and the other authors of Creating a Nation 'aimed not so much to discredit the old stories as to advance a new one, with women not alienated from, but central to, nation-building..$^{18}$ In doing so, they sought to construct 'the national subject as feminine', rather than constructing women as national subjects. Such a distinction is significant. The latter would arguably amount to constructing women, conceptually, as masculine subjects because the 'national subject' (the normative citizen) was based on a particular, male experience of citizenship.

Lake also described how a rigid conceptualisation of 'politics' had rendered many of women's political contributions invisible to those who recorded political histories. For example, referring to Judith Smart's study of the citizen activism of the largest women's organisation in Australia of its time, the Victorian Housewives Association and the Federated Association of Australian Housewives, Lake described how the organisation's leader, Cecelia Downing, had 'effectively disappeared from public memory while the names of some contemporaries, such as Enid Lyons, have survived'. ${ }^{19}$ She argued that, because Lyons had entered institutional politics, it would seem that political power, like sexual power, has to be visible to be seen to exist'. ${ }^{20}$ Lake suggested that Lyons is celebrated while Downing is not because Lyons was the first woman to be elected to an Australian parliament (albeit toward the end of what had already been a long political life outside of institutional politics), and because parliaments 'have solid visual form'. ${ }^{21}$

17 Ibid., 154

18 Ibid., 155

19 Ibid., 160.

20 Ibid.

21 Ibid. 
Lake's critiques of liberal or egalitarian feminist approaches to documenting women's political histories arguably positions her work within a feminism of difference. Feminisms of difference emerged from the 1970s and 1980s within the context of, for example, the feminist theory emerging from France as well as women's liberation and countercultural movements in the West that focused on celebrating or valorising, rather than transcending, the female position. Lake's work challenges notions of citizenship and politics that exclude women's actual experiences of politics, and she sought to construct women as political subjects based on women's distinct experiences outside of the privileged, masculine institutions. Lake aimed at reimagining women as legitimate political subjects rather than 'political failures'; I argue further that there remains a risk of reinforcing the normativity of masculinist modes of citizenship if we valorise women's political practices while characterising them as primarily a means to an end or a way of 'making do'. Even Lake, who defended Australian suffragists and postsuffrage feminists (whose goals were not necessarily to enter parliament but to influence policy in different ways, including by voting), wrote that women's 'distinctive modes of doing politics' were formed by women's 'lack of mobility and autonomy'. ${ }^{22}$ As I argue with this paper, feminist scholarship should be critical of characterising women's political activities as 'lacking', and should be developing ways of conceptualising it, as I describe, as legitimate and 'whole'. Such reconceptualisations are significant for feminist theorising. While it would be reckless to deny women's suffering based on our social, political and cultural subordination and oppression, we must also ask how we could engage in more critical approaches that disrupt the normativity, or false universality, of the masculine subject. I suggest that Irigaray's feminist philosophy offers ways of reimagining and reconceptualising women's non-institutional and non-party political practices in such ways.

\section{An Irigarayan Politics as (Women's) Radical Politics?}

Luce Irigaray is most well-known for her critiques of the phallocentrism of Western philosophy and psychoanalysis (particularly in Speculum of the Other Woman, in which she offers a substantial critique of the works of Plato 
and Freud). She is also known for her thought on sexual difference and for her assertion of the ontological, not only socially constructed, nature of what she terms 'sexuate' identity. Her work critiques a phallocentric culture of 'sexual indifference' that positions 'Man' as the universal (or neutral) subject and 'Woman' as the 'particular' - that is, a deviation from the male subject. 'In Speculum', she later wrote, 'I interpret and critique how the philosophical subject, historically masculine, has reduced all otherness to a relationship with himself-as complement, projection, flipside, instrument, nature—inside his world, his horizons. ${ }^{23}$

Throughout her work, Irigaray develops an argument for rethinking sexual difference, and feminism, based on a rethinking of the categories of subject and other. In response to Simone de Beauvoir's work in The Second Sex (1949), she argues that women should indeed lay claim to the position of 'other' rather than transcending it (as she suggests Beauvoir's work advocates). She critiques Beauvoir's thinking on the categories of 'subject' and 'other', in particular suggesting that Beauvoir fails to critique the implicit masculinity of the 'subject' in Western thought and culture. Irigaray suggests that by laying claim to the category of 'other' - a category that is different to the masculine subject-women could cultivate our own subjectivities, rather than aiming to join the already existing masculine subject position. In a 1995 paper, Irigaray described her position as the 'inverse' of Beauvoir's, 'as far as the question of the other is concerned'. ${ }^{24}$ She had earlier described the conceptual position of women in patriarchal thought and culture as the other side of the sex that alone holds a monopoly on value: the male sex'. ${ }^{25}$ Rather than aiming for equality, or for women to join men in the position of the subject, Irigaray argued that subjectivity itself needed to be rethought in the West to acknowledge the possibility of (at least) two different but non-hierarchical subjects. She wrote, for example:

The question of the other has been poorly formulated in the Western tradition for the other is always seen as the other of the same, the other of the subject itself, rather than an/other subject, irreducible to the masculine subject and sharing equivalent dignity. ${ }^{26}$

23 Luce Irigaray, 'The Question of the Other', Yale French Studies, no. 87 (1995): 10.

24 Ibid., 8.

25 Luce Irigaray, This Sex Which is Not One (Ithaca, New York: Cornell University Press, 1977/1985),

26 Ibid. 
Such a logic, as Irigaray's argument goes, denies women a subject position in our own right and in our own terms; women do not occupy a position as 'woman' but are relegated to the position of 'not-man'. In this sense, women are positioned only ever in relation to the supposedly universal, neutral and stable subject: 'Man'. Irigaray's philosophical work is in this sense grounded in her commitment to affirming women's specificity (while acknowledging the plurality among and between women) and therefore a subjectivity of our own. She argues that such a subjectivity is not currently represented (or indeed possible) in Western thought and culture. Her philosophical work is therefore concerned with not only critiquing the phallocentrism of Western thought and culture but, as Margaret Whitford describes, with working out the conditions of women's subjectivity-how women can assume the "I" of discourse in their own right'. ${ }^{27}$

These perspectives have informed what is known as the 'creative' (as opposed to the critical) phases of Irigaray's work as well as a lengthy discussion, in Irigaray's second feminist text This Sex Which is Not One (first published in French in 1977 and translated into English in 1985), on politics and women's political practices. Irigaray discussed women's relations to politics and the need for women to cultivate a 'new' politics-particularly in the context of the women's liberation movements in France, and elsewhere in the West, in the 1970s. In her discussion on politics, Irigaray argued that women of this time needed to create a politics that did not reinforce political practices, ideals and systems that men had typically adopted. She critiqued then conventional modes of practising politics, arguing that 'strictly speaking, political practice, at least currently, is masculine through and through'. ${ }^{28}$ She also argued that a feminist politics that emulated the ways that men had practised politics would be limited in its transformative capacity. For women to be able to make ourselves heard, Irigaray argued, 'a "radical" evolution in our way of conceptualising and managing the political realm is required'. ${ }^{29}$ She wrote:

No "women's politics" exists, not yet, at least not in the broad sense. And, if such a politics comes into existence one of these days, it will be very different from the politics instituted by men.

27 Margaret Whitford, Luce Irigaray: Philosophy in the Feminine (London; New York: Routledge, 1991), 42 .

28 Irigaray, This Sex, 127.

29 Ibid. 
For the questions raised by the exploitation of women's bodies exceed the stakes, the schemas, and of course the "parties" of the politics known and practiced up to now. ${ }^{30}$

Irigaray's scepticism about women's entrance into the kinds of politics 'known and practiced to now' meant that she warned against the merits of 'equality feminist' aims, including advocacy for the equal representation of women and men in political institutions. She argued that political parties could 'co-opt' the so-called woman question by 'granting women a place in their ranks' and argued that such gestures were merely aimed at 'aligning [women] —one more time ...-with their "programs", which most of the time, have nothing to do with them, in the sense that these programs fail to take into consideration the specific exploitation of women'. ${ }^{31}$ Not only did Irigaray, in this sense, reject prioritising women's entrance into male political systems (which would amount to women fulfilling the role of dutiful daughter, upholding the rule and existing practices of men), but she emphasised that, for her, women's exploitation was deeper than the level of material or social oppression. She said that the exploitation of women does not constitute a limited question, within politics, one which would concern only a "sector" of the population or a "part" of the "body politic"'. ${ }^{32}$ Irigaray argues rather, as the psychoanalytic aspects of her work seek to demonstrate, that women's oppression is grounded in and perpetuated by the lack of symbolic representation of women and women's experiences in Western thought and culture. Women's bodies, desires and language have been denied expression in women's own terms: the culture (including political theories and practices) that women inherit is a masculine one. In this sense, egalitarian feminist aims are considered highly conservative. Irigaray's feminist aims are much more radical:

When women want to escape from exploitation, they do not merely destroy a few "prejudices", they disrupt the entire order of dominant values, economic, social, moral, and sexual. They call into question all existing theory, all thought, all language, inasmuch as those are monopolised by men and men alone. They challenge the very foundation of our social and cultural order, whose organisation has been prescribed by the patriarchal system. ${ }^{33}$

30 Ibid., 165.

31 Ibid.

32 Ibid.

33 Ibid. 
Importantly, while Irigaray points out the limitations of egalitarian feminisms, she does not deny the need for material and social rights-nor the need to demand these in an organised way. She cautions, however, that while women must 'continue to struggle for equal wages and social rights, against discrimination in employment and education, and so forth', this is 'not enough'. ${ }^{34}$ Women 'merely "equal" to men', she said, 'would be "like them", therefore not women'. ${ }^{35}$ In other words, aims for equality leave existing conceptions of the 'subject' intact, and this is a singular, masculine subject—one cultivated by men.

Whitford suggests that Irigaray 'does not recommend that women enter the political arena as it at present exists' but that she accepts 'that this can be a strategic necessity'. ${ }^{36}$ Whitford also suggests that it 'would be very easy to misread' Irigaray's position as not taking women's social and material oppression seriously. However, she argues that Irigaray's aim of a transformation of 'the foundation of our social and cultural order' is not dismissive of more immediate political concerns: ${ }^{37}$

In fact, Irigaray suggests that we need to distinguish between struggle and critique on the one hand, and the long-term vision on the other. The local struggles are important, even essential, but to lose sight of the larger objective would mean that women become assimilated to the world of men and then have nothing to contribute as women (as is made clear by the problems inherent in applying classical liberal theory to women)..$^{38}$

In other words, equal rights should, for Irigaray, be considered a means to an end and not the end itself. She emphasised, for example, that claims to social freedoms 'must never disguise the fact that it is in order to bring their difference to light that women are demanding their rights. ${ }^{39}$ To therefore avoid the differences between women and men being 'cancelled out, ignored, papered over' by becoming assimilated into the 'world of men', Irigaray argued that it was essential 'for women among themselves to invent new modes of organisation, new forms of struggle, new challenges'. ${ }^{40}$ She recognised that the women's movements in the

34 Irigaray, This Sex, 165-6.

35 Ibid.

36 Whitford, Philosophy in the Feminine, 12.

37 Irigaray, This Sex, 165.

38 Whitford, Philosophy in the Feminine, 12.

39 Irigaray, This Sex, 166.

40 Ibid. 
West at this time had already begun to do this, particularly through women's ways of gathering together through consciousness-raising groups. However, she implored that 'innovation is necessary: institutions, hierarchy, and authority - that is, the existing forms of politics—are men's affairs' and 'not ours'. ${ }^{41}$ She warned that if 'women allow themselves to be caught in the trap of power, in the game of authority, if they allow themselves to be contaminated in the "paranoid" operations of masculine politics' then women will 'have nothing more to say or do as women'. ${ }^{42}$

Anti-essentialist and poststructuralist feminists have been understandably wary and critical of Irigaray's work because her arguments are grounded in an affirmation of women's specificity and difference from men. Some argue that this risks falling into (or indeed does fall into) essentialist claims about precisely what this difference is or where it originates. Questions about apparent essentialism in Irigaray's work remain a topic of debate in Irigarayan scholarship. However, it is important to understand and acknowledge the philosophical interventions that Irigaray's work offers to feminist thought-in particular, her rethinking of subjectivity, the category of the other, and difference. In terms of thinking about women's experiences of politics, this helps us to ask important questions about women, citizenship and political subjectivity. If women are granted access to phallocentric political institutions, what legacy do we inherit? What political subjectivity do we occupy? If women practice politics in the ways that men conventionally have done, what systems, ideals and institutions does this sustain? And, on the other hand, what would a political subjectivity articulated and cultivated in women's own termsand in a way that disrupted the logic that positions women always ever in relation to men-look like?

\section{Reading Women's Political Theories and Practice in Australia as Radical}

Many parallels with Irigaray's calls for feminist innovation in political practice can be found in Lake's interpretations of women's nineteenth-and twentieth-century political theories and practices in Australia. As discussed previously, Lake has aimed to counter the myth that women in Australia 
lacked a robust political history by drawing attention to the energetic and influential ways that women practised politics as activists, advocates, writers, speakers, community members and 'citizen politicians'. Could the political practices that women engaged in throughout the nineteenth and twentieth centuries in Australia (and that women continue to engage with in twenty-first-century Australia) embody the 'new' political practices that Irigaray advocated for in the 1970s? Lake has emphasised that women's political thought and practices were distinct. In other words, they were not merely 'deficient' versions of men's political practices and ideals but were often based in active critiques of institutional and party politics. The anti-party stance of feminists like Louisa Lawson, Vida Goldstein and Rose Scott as documented in Lake's work, for example, were often grounded in a rejection of conventional political practices.

Lake's work has also highlighted the ways that nineteenth- and twentiethcentury feminists' approaches to politics in Australia often sought to foreground, rather than neutralise, women's specificities and the unique perspectives, experiences and oppressions of women. Lake has suggested, for example, that it was faith in the collective power of the vote as an expression of woman-power that ... animated feminists' strong opposition to women's engagement in party politics'. ${ }^{43}$ It was assumed that 'if women's interests were subsumed in men's parties, "woman's voice" would be rendered inaudible'. ${ }^{44}$ Later feminists, Lake suggested, had 'some difficulty in coming to terms with the priority accorded by suffragists to voting rights' (over parliamentary representation). She argued that this risked misunderstanding and misrepresenting Australian suffragists' political purpose, however, 'which was broad social reform, not merely or primarily, the advancement of women'. ${ }^{45}$

Australian suffragists including Louisa Lawson explicitly opposed women's engagement in party politics. In 1890, pre-suffrage, Lawson had written in The Dawn, for example, that 'few women would care for such a [parliamentary] post' and that 'there is no woman who would not think of her baby and the happiness of her home long before she desired in her wildest fancies the barren honour of a parliamentary seat'. ${ }^{46}$ There are problems with Lawson's characterisation of a parliamentary

43 Lake, 'Feminist History as National History', 164.

44 Ibid.

45 Ibid.

46 Louisa Lawson, 'Women Members', Dawn, June 1890. 
position as a 'barren honour' and her categorical characterisation of parliament as a place 'unfit for women' (and presumably unable to change), of course. Irigaray's feminist perspective, for example, does not deny the importance of women being in the positions of greatest societal power. However, we must also be critical of the ways in which institutional political places and systems might be unfriendly to women or unable to serve and respond to women's experiences (like motherhood), needs and desires-as Lawson suggests here. As Lake suggested, the goal for many feminists at the time of the women's suffrage campaign was not, in many instances, women's equal representation in parliament but the power of the ballot. ${ }^{47}$ Many feminists refused to participate in institutional politics on men's terms, and the parliamentary system was considered one of them. Rose Scott similarly opposed women's participation in institutional politics. She said, in a 1904 address to the Women's Political Education League, for example, that 'our place as women is not as camp followers to a corrupt system of Party politics, but as women to be men's inspiration to higher and nobler methods of governing a country'. ${ }^{48}$ She described, further, how:

At both Federal and State elections we issued manifestos urging women to keep away from sectarianism and party politics, and to work for the interests of women and children which have been so long neglected. Many who saw no reason in this warning have since assured me that they are now quite convinced, through bitter experience, of the necessity for women (who desire to work for reform in a whole-hearted manner) to keep apart from the factions and fights of men. ${ }^{49}$

Feminists in Australia like Scott were adopting critical political practices outside of men's institutions as legitimate alternatives to the political status quo-not (or at least not only) because of a lack of masculine political power. Vida Goldstein similarly had strong anti-party ideals, though she campaigned as an (independent) electoral candidate. She wrote in the journal Woman's Sphere in 1903, for example, that:

Women should carry on the fight and the campaign by means of their own organisations, and not by means of any of the existing ones controlled and directed by men. If they do the latter, they

47 Lake, 'Feminist History as National History', 164-5.

48 Rose Scott, President's Address to the Women's Political Education League, 1904, Mitchell Library.

49 Ibid. 
must adopt men's methods and men's aims, and simply help in perpetuating the old order of things. The right of the franchise will have been bestowed on them for no purpose. ${ }^{50}$

Later, in 1909, in The Woman Voter, Goldstein again defended feminists' non-party stance, writing:

By adopting (a non-party) policy it is not to be supposed that we are a body of gelatinous creatures, who have no definite views. We have all got very decided views as to the merits of the various political parties - some of us are protectionists, some are socialists, but we differ from those organised on party lines in one important particular. We believe that questions affecting the welfare of children, the present salvation of the criminal and the depraved, the moral, social and economic injustice imposed on women-we believe that all these questions are greater than party, and that in nine cases out of ten they are sacrificed to party interests. ${ }^{51}$

As Irigaray is critiqued for affirming women's specificity, feminists like Lawson, Goldstein and Scott were criticised by later feminists for their seemingly conservative or separatist views. For example, Judith Allen recalled in the preface to her book Rose Scott: Vision and Revision in Feminism what, at the time, 'an embarrassment earlier women's movement activists like Scott were to young feminists in the 1970s' because of, in this case, Scott's firm opposition to mixed-sex surf bathing in Australia. ${ }^{52}$ Irigaray has argued for the necessity of female places and spaces for women (where we could cultivate our subjectivities and 'sexuate' identities), but critiques of her as separatist or conservative are limited. Irigaray makes it clear that she opposes a strictly separatist feminist agenda. In This Sex Which is Not One, for example, she argued for the significance of a 'female-to-female sociality', but she emphasises that a female sociality should not signify a mere reversal of the patriarchal order. A female-to-female sociality is necessary for feminist politics, she argued, because women 'have always been put in a position of mutual rivalry' and so 'to make their own efforts more effective, they have had to constitute a place where they could be "among themselves". ${ }^{53}$ Such places could be a 'place for individual and

50 Vida Goldstein, 1903, quoted in Lake, Getting Equal, 145.

51 Vida Goldstein, The Woman Voter, no. 1, August 1909; Anne Summers, Damned Whores and God's Police: The Colonization of Women in Australia (London: Allen Lane, 1994), 412.

52 Judith Allen, Rose Scott: Vision and Revision in Feminism (Melbourne; New York: Oxford University Press, 1994).

53 Irigaray, This Sex, 160. 
collective "consciousness-raising" concerning the specific oppression of women, a place where the desire of women by and for each other could be recognised, a place for them to regroup' ${ }^{54}$ But she warned that womenonly spaces were in danger of becoming a utopia of historical reversal, a dream of reappropriation of power'. ${ }^{55}$ Women's political activities have often been, and continue to be, practised in groups with other women. It is important to consider the significance of these female-only or femaledominated spaces, particularly in terms of what they might offer for the cultivation of women's political subjectivities and political practices.

\section{Women's Modes of Politics as an Irigarayan Politics of Relationality}

While Irigaray's early work focused on the need for women, specifically, to cultivate a different approach to doing politics, she has written more recently on the need to develop a new mode of doing politics more generally. Her recent writing on politics offers further resources, I suggest, for reconceptualising women's non-institutional political theories and practices because of her particular attention to relationality. As Lake's work demonstrated (particularly in the 1990s), women's political activity has historically occurred with closer relation to the realms of society that are closest to the home and often in 'informal' groups together with other women. (And it still often does in contemporary Australia.) Women's closeness to the home, family and local community-as well as the associated closeness and attention to natural (and bodily) rhythms — can be characterised as limitations or barriers to women's political subjectivity or citizenship. However, Irigaray's privileging of relationality and attention to nature in her recent rethinking of politics might enable us to think of these aspects of women's political activity in new ways. In a 2019 interview, for example, Irigaray suggests that, 'a new global politics based on the respect for life is necessary', and she begins to imagine what this politics might be and how it could be enacted. ${ }^{56}$ This attention to care and relationality in Irigaray's work has some parallels with feminist writing on developing an ethic of care. In Lake's more recent work, for example,

\footnotetext{
54 Ibid., 160-1.

55 Ibid.

56 Luce Irigaray and Stephen Seely, 'What Does It Mean to Be Living?' PhiloSOPHIA, 8, no. 2 (2019): 8.
} 
she has emphasised the ethic and politics of care that grounded many women's political theory and practice in the nineteenth and twentieth centuries in Australia. ${ }^{57}$

In Irigaray's recent writing on politics, she speaks of desiring a politics that is grounded in 'care about oneself' and that does not rely on a 'codified and presumably neutral civic identity, which cuts [one] off from their real "identity". ${ }^{58}$ For Irigaray, this care of oneself would ground a 'politics between two. ${ }^{59}$ She also describes how, in imagining a new politics, she had begun to practice 'a politics of the relation between two', which she said 'allows for the respect for life and difference(s) — at each time and on any occasion of the day' ${ }^{60}$ She added that she 'also understood that my undertaking was above all to work on the elaboration of a new cultural background from which a new way of practicing politics could little by little arise'. ${ }^{61}$ The politics that Irigaray imagines could (or indeed should), in this sense, begin at a cultural level, rather than a systemic level-from the bottom up. She suggests that we must develop a new way of relating before we can develop a new politics, or perhaps that this way of relating could be a mode of politics in itself —or a way of bringing about political change. This is not a new development in Irigaray's thought. Her writing in the 1990s and 2000s began to elaborate this notion of relational politics 'between-two', based in an ethic of love and her thinking on 'intersubjectivity' (including, I Love to You [1996], Democracy Begins Between Two [2001], The Way of Love [2002] and Sharing the World [2008]). Her more recent philosophical works (such as Through Vegetal Being [2016], To Be Born [2017] and Sharing the Fire [2020]) bring themes of the 'natural' world, life and natural rhythms to the foreground. Could the attention to the care of oneself and relationality between (at least) two be found in the ways that women in Australia have practised non-party and non-institutional politics? Could we describe what Lake considered to be women's 'distinct' modes of practising politics as an Irigarayan relational politics, and, in this sense, a radical politics?

57 Lake, 'Subjective Femininities and Feminist Subject Positions'.

58 Irigaray and Seely, 'What Does It Mean to Be Living?', 6.

59 Ibid.

60 Ibid.

61 Ibid. 


\section{Writing About Women's Historical and Contemporary Political Practices with Irigaray}

In this paper, I have responded to Marilyn Lake's call to develop new feminist conceptual frameworks for understanding women's political practices by looking to the work of French feminist philosopher Luce Irigaray. I have argued that it is not enough to merely document women's non-institutional and non-party political activities without adopting a critical feminist approach. Doing so, I have argued, risks reinforcing the normativity of masculine modes of politics, citizenship and subjectivity, and characterising women's distinct modes of politics as merely lacking or deficient forms of 'real' politics. Instead, I have suggested that it is possible to reconceptualise women's distinct modes of politics as a radical—and perhaps Irigarayan-politics that actively challenges the conventions of male political power, citizenship and practices. Conceptualising women's political practices in this way disrupts the false universality of the masculine political subject and phallocentric notions of 'politics'. I have shown how Irigaray's work can inform such an approach. I have considered Irigaray's writing on the need for women to create new modes of doing politics that do not emulate existing, masculine politics as well as her argument for the disruption of the universality of the masculine subject and the articulation of women's subjectivities. The discussion outlined in this paper could, I suggest, inform ways of telling women's political histories and of understanding women's contemporary experiences of noninstitutional politics in new ways. By thinking about women's politics as radical rather than as deficient, I argue that it is possible to conceptualise women's political histories as legitimate and meaningful political histories, and women's political practices as constituting a legitimate and meaningful politics. 
This text is taken from Lilith: A Feminist History Journal: Number 26, published 2020 by ANU Press, The Australian National University,

Canberra, Australia.

doi.org/10.22459/LFHJ.26.04 